Institute of $\mathbf{F}_{\text {ood and }} \mathbf{A}_{\text {gricultural }} \mathbf{S}_{\text {ciences }}$

\title{
Irrigating Landscape Plants During Establishment ${ }^{1}$
}

\section{Edward F. Gilman²}

Even the healthiest trees planted in the most ideal circumstances need a substantial amount of time, care and, particularly, proper irrigation, to become established in the landscape (Table 1). During the establishment period, roots are expanding out into the landscape soil, and shoots and trunk grow more slowly than they did before transplanting. (Figure 1) Once shoot and trunk growth rates match the rates before planting, the tree is considered established. An established tree has developed a root system substantial enough to keep it alive without supplemental irrigation.

Establishment occurs more rapidly in warm climates and when irrigation is supplied in correct quantity and frequency. Irrigation is especially important in Florida. Trees transplanted from containers take longer to establish and therefore require supplemental irrigation for a longer period than do field-grown trees. Research indicates that establishment time for container-grown trees can be an additional 1 to 2 months per inch of trunk diameter. If supplemental irrigation is halted too soon, or if it's not applied often enough, the mortality rate for container grown trees will be higher than for hardened off field-grown trees.
In addition to requiring special attention to irrigation, trees in the establishment period need mulching and may require staking, especially those planted from containers. Pruning and fertilization are also handled in specific ways during the establishment period.

When trees die, blame is often placed on pests, disease, the method by which they were produced or the plants themselves. The truth is that many trees die from too little or too much water during the first few months after planting. Trees are likely to get too little water in well-drained soil and too much in soil that is poorly drained.

Determine when and how much to water by becoming familiar with the characteristics of the planting site and then striving to maintain constant moisture in (but not saturation of) the root ball. The variables shown in Table 2 will affect the irrigation schedule at a given site. Remember that the proper frequency and duration of irrigation may vary slightly from one site to the next, so the moisture level in the root ball is the final determinant of whether irrigation is being correctly supplied. Monitoring this is more practical in some locations than in others.

The practice of intense irrigation management can save resources in the long term. While less

1. This document is ENH857, one of a series of the Environmental Horticulture Department, Florida Cooperative Extension Service, Institute of Food and Agricultural Sciences, University of Florida. Original publication date December 26, 2002. Visit the EDIS Web Site at http://edis.ifas.ufl.edu.

2. Edward F. Gilman, Professor, Plant Environment, Environmental Horticulture, Cooperative Extension Service, Institute of Food and Agricultural Sciences, University of Florida, Gainesville, 32611.

The Institute of Food and Agricultural Sciences is an equal opportunity/affirmative action employer authorized to provide research, educational information and other services only to individuals and institutions that function without regard to race, color, sex, age, handicap, or national origin. For information on obtaining other extension publications, contact your county Cooperative Extension Service office. Florida Cooperative Extension Service/Institute of Food and Agricultural Sciences/University of Florida/Christine Taylor Waddill, Dean. 
frequent irrigation over a long period of time spreads out the cost of irrigation, the dollar amount spent will be about the same as for intensively irrigating trees for a short period of time. Intensive irrigation results in trees that establish more rapidly and thus become more quickly resistant to drought, pests and disease. The concentrated up-front costs of intensive irrigation are thus offset by lower mortality and healthier trees.

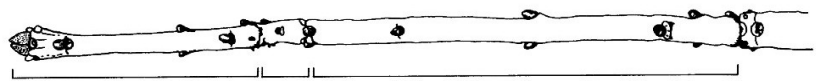

Figure 1. Twig from a tree not yet established in the landscape. Growth in the second year was greater than in the first year after transplant.

\section{Irrigation Systems}

Problems may arise if newly planted trees are irrigated by systems designed to water turf, flower beds or established plants. In well-drained soil, such systems cannot supply enough water to the new trees without overwatering everything else and wasting water. These trees must be watered by hand with a hose or with a temporary micro-irrigation system designed specifically for them. Properly designed, this system can tap into the existing irrigation system. Once trees are established and their roots spread out, the usual irrigation system will be adequate, and the temporary system can be removed.

In poorly-drained sites, trees planted in or near regularly irrigated turf are especially susceptible to over-watering. Irrigation water and rainfall run over the soil surface and collect in the looser soil of the planting hole, drowning the trees' roots. For this reason, trees are best located away from the turf and its irrigation system, in their own specially irrigated beds. If this is not possible, adjust the turf irrigation system so that the root balls of the newly planted trees do not become saturated. This solution may, however, result in under-watered turf. A third and highly recommended solution is to plant trees slightly higher than surrounding soil. This keeps the top portion of the root ball out of the standing water in the planting hole.

\section{Frequency of Irrigation}

In order to maintain rapid growth, trees transplanted into well-drained soil require daily irrigation for at least two weeks (Table 3). Frequent irrigation benefits the transplanted tree more than large volumes of water infrequently applied. In well-drained soil, apply water to the root ball every day during the first few weeks after planting. Irrigation conducted according to the schedule in Table 3, left column, will provide for the most rapid establishment. At this stage, all of the tree's roots are still located in the root ball. However, you may wet surrounding soil if it is dry.

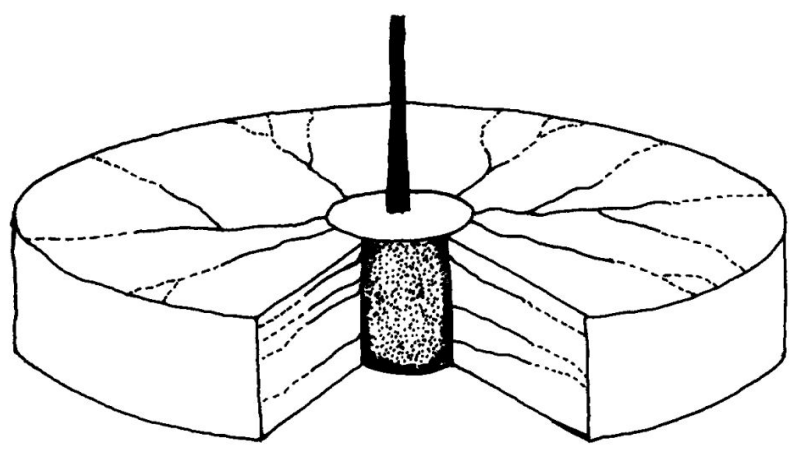

Figure 2. Solid lines indicate root growth under less than optimum soil moistre conditons. Dotted lines show the root growth possible with frequency and regular irrigation.

In poorly-drained soil, a set irrigation schedule may be impractical. Instead, monitor the site for changes in moisture levels caused by rainfall or, possibly, run-off from adjacent irrigation.

Essentially, the root balls of newly planted trees must not be allowed to dry out, nor must they be saturated. It is easy to kill trees that have been planted into poorly drained sites.

Maintaining adequate moisture in the root ball and surrounding soil allows for faster and more extensive root growth (Figure 2). The more rapid the root growth, the faster the rate of establishment and the sooner the tree develops a resistance to drought. Root growth is slow on trees that are not irrigated regularly after planting. Such trees may stay alive until a drought occurs but can die back during the drought. Regular irrigation in loose soil promotes the extensive root system that is a tree's best defense against drought. 
Trees without adequate irrigation during the establishment period may also develop a weak, multi-trunk habit (Figure 3). This can happen in response to dry-weather-induced tip die-back on the main trunk and branches. When wet weather returns, several new shoots often emerge from the living tissue behind the dead tips. These shoots can become equally dominant with the trunk, resulting in several trunks and an inferior, poorly structured tree.
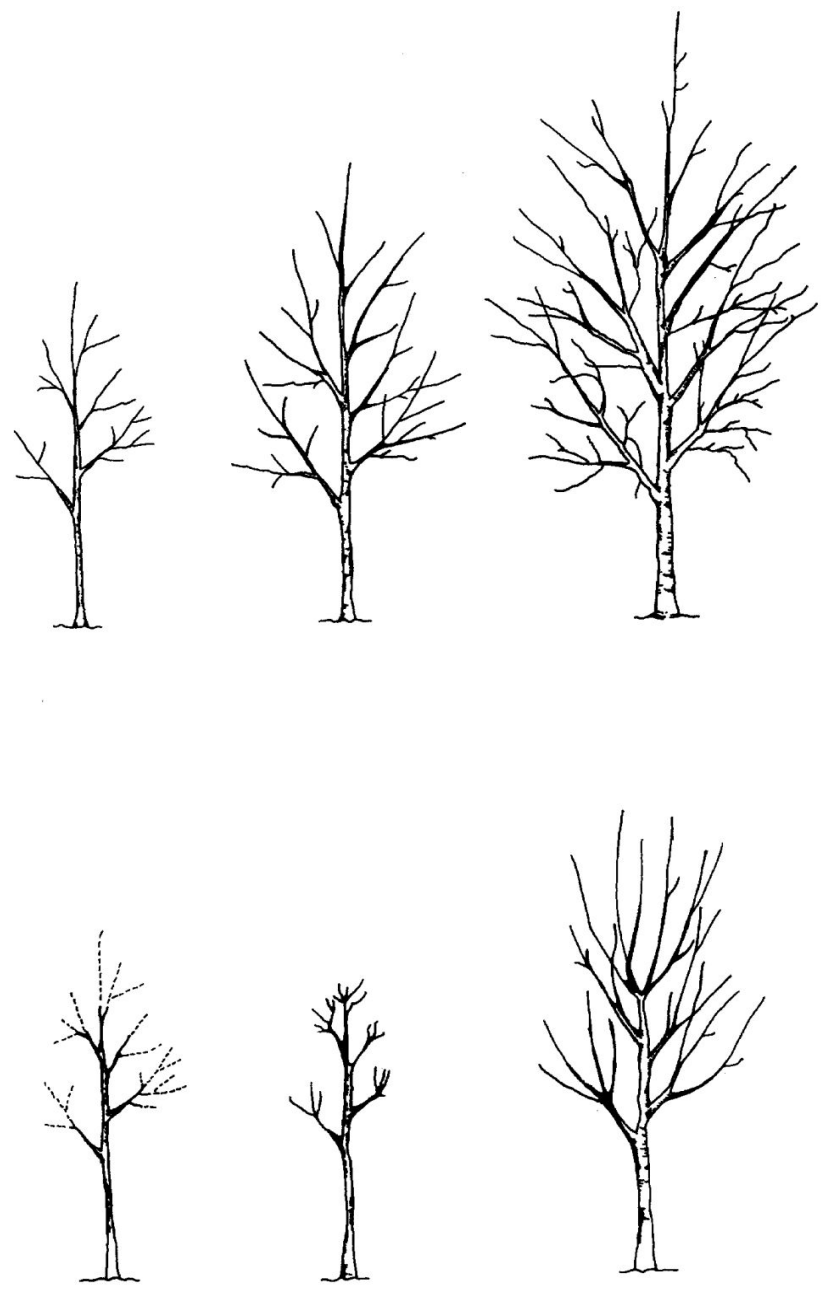

Figure 3. A tree of high quality that receives adequate irrigation during establishment (Top) develops good structure, while trees that are insufficiently irrigated (Bottom) die back (as indicated by dotted lines) and can develop multiple trunks or other types of poor form.

In the first few months after planting, do not skip an irrigation because of rainfall, unless it measures over an inch. Rain water during the growing season should not be counted on to provide any benefit in the first few months after transplanting. Later, normal rainfall should provide enough soil moisture in most years to allow for adequate tree root growth into the soil surrounding the root ball. If the site has no irrigation system or if there is a drought, occasionally water the soil surrounding the root ball. If this soil becomes too dry, root growth will be slow. Gradually increase the irrigation area around the tree to accommodate root growth. During the first few years after planting, roots grow 1 to 2 inches per week in Florida.

\section{Amount of Irrigation}

The best way to determine how much irrigation to apply to container-grown trees in the first several weeks after planting into well-drained soil is to ask the nursery operator how much was applied in the nursery just prior to purchase. Apply this amount or slightly more directly to the root ball. There is no need to wet the surrounding soil at this time because it will be wetted by water draining from the container root ball and by rainfall. Container grown trees planted into poorly drained soil may need a smaller volume of irrigation than they received in the nursery. If you are not able to determine the amount of irrigation trees were receiving in the nursery, use the guidelines below for field-grown trees.

As a rule of thumb for field-grown trees, 1 1/2 to 3 gallons of water per inch of trunk diameter applied each time the tree is irrigated during the growing season should be enough to maintain adequate root growth. For example, a tree with a 2-inch trunk diameter needs about 3 to 6 gallons each time it is irrigated. Trees planted during the cooler months may need less water, depending on the weather and soil drainage. Those planted in compacted or poorly drained soil with a portion of the root ball above the surrounding soil may need more water due to the drying effect of the mounded planting. Trees mistakenly planted too deeply in poorly drained soil should not be irrigated until they are raised and replanted. Trees with more than about one inch of mulch over the root ball may need more volume to allow enough water to drain through the mulch and reach the root ball.

To determine whether the amount of water being supplied is adequate for the site conditions, conduct the following tests: Within the first week after planting, gently dig a small hole in the loosened 
backfill soil just outside the root ball and half its depth. Do this several hours after watering. Squeeze soil taken from the bottom of the hole in the palm of your hand. If water drips out between your fingers, you are watering too much; if soil crumbles and falls out of your hand as you open your fingers, you are watering too little. If soil stays together as you open your fingers, moisture in the backfill soil is just right. Poke a finger into the root ball to check the moisture there. If it feels dry, increase the amount of daily irrigation. If the soil smells sour or you can squeeze water from it, it is too wet. With practice, these techniques become quick and easy ways to evaluate soil moisture.

Some people use a soil probe to judge soil moisture. If the probe is easy to push into the root ball, soil moisture may be fine; if penetration is difficult, you may need to increase irrigation. Soil moisture sensors with various types of gauges are designed to help schedule irrigation for established landscapes. There is no published evidence of their usefulness in judging when newly planted trees need watering.

\section{Managing with Less Water}

If proper irrigation cannot be provided following planting, consider planting smaller trees, which establish more quickly, or extend the irrigation period following planting to conform to Table 3 .

\section{More Information}

For more information regarding tree planting, visit http://hort.ifas.ufl.edu/woody/planting 
